\title{
A comparison of cost for mycobacterial load determination in research laboratories
}

\author{
A Pooran, ${ }^{1}$ MSc, BSc (Hon); R Meldau, ${ }^{1}$ BSc Med (Hon); K Dheda, ${ }^{1,2}$ MB BCh, FCP (SA), FCCP, PhD, FRCP; \\ R N van Zyl-Smit, ${ }^{1,3} \mathrm{MB}$ ChB, MRCP (UK), MMed, FCP (SA), Cert Pulm (SA), PhD \\ ${ }^{1}$ Lung Infection and Immunity Unit, Division of Pulmonology; and University of Cape Town Lung Institute, Department of Medicine, University of Cape Town, \\ South Africa \\ ${ }^{2}$ Institute of Infectious Diseases and Molecular Medicine, University of Cape Town, South Africa \\ ${ }^{3}$ Lung Clinical Research Unit, University of Cape Town Lung Institute, South Africa
}

Corresponding author: $R$ van Zyl-Smit (richard.vanzyl-smit@uct.ac.za)

\begin{abstract}
Background. Mycobacterial load determination is a critical quantitative measure needed in many clinical and research laboratory studies and selection depends on several factors including sensitivity, dynamic range and turnaround time. However, there are no data about cost, which is an important selection determinant. We therefore performed a cost analysis of five quantitative mycobacterial load assays.

Methods. The costs of five mycobacterial quantification techniques were compared in a hypothetical single experiment (control and intervention) performed in triplicate. Assays evaluated were: mycobacterial colony-forming units (MCFU) using 7H10-Middlebrook solid media, automated liquid culture (BACTEC-MGIT-960), [ $\left.{ }^{3} \mathrm{H}\right]$-uracil incorporation assays, luciferase-reporter construct bioluminescence, and quantitative polymerase chain reaction (PCR) (Xpert-MTB/RIF) using serial dilutions of Mycobacterium tuberculosis. Costs associated with consumables, equipment and personnel were included and expressed in 2015 South African rands and US dollars.

Results. The least costly technique was the luminescence reporter construct assay (R85.68/\$6.72) whereas the most expensive technique was the Xpert MTB/RIF PCR (R388.02/\$30.42). The high cost of the PCR assay was mainly attributable to the costly Xpert MTB/RIF cartridges. Although the MCFU by solid culture had a similar cost compared with uracil incorporation and Xpert MTB/RIF, the purchase price of the equipment required to perform the latter assays was $\sim 2$ - 10 times higher.

Conclusion. Taking into consideration the turnaround time, capital costs, discriminatory ability, the running costs (excluding staff) of the luminescence reporter assay are the lowest. Where time to result is critical, more expensive techniques such as the Xpert MTB/RIF should be used. In a clinical setting where automated culture and Xpert are routinely performed, quantitative load from time to positivity and cycle thresholds will provide extra data without additional cost.
\end{abstract}

S Afr Resp J 2015;21(3):55-58. DOI:10.7196/10.2015.v21i3.55

Basic science research is a critical part of the fight against tuberculosis. Better understanding of the targeted immunological response, effects of drugs on mycobacterial survival and immune responses to novel vaccines is needed. A key part of this research is defining the mycobacterial load in any given assay sample. ${ }^{[1-3]}$ We have previously published a comparative study investigating the utility and performance characteristics of five quantitative load determination techniques, namely: mycobacterial colony-forming units (MCFU) using 7H10-Middlebrook solid media, automated liquid culture (BACTEC-MGIT-960), [ $\left.{ }^{3} \mathrm{H}\right]$-uracil incorporation assays, luciferasereporter construct bioluminescence, and quantitative polymerase chain reaction (PCR) (Xpert-MTB/RIF) using serial dilutions of Mycobacterium bovis and M. tuberculosis H37RV. ${ }^{[4]}$

In this study no single assay had 'perfect' performance characteristics: the automated BACTEC-MGIT-960 (MGIT) had the lowest detection threshold but a long turnaround time, the Xpert MTB/RIF assay had a rapid turnaround time but a higher (poorer) detection threshold. The bioluminescence and tritiated uracil showed poor discriminative ability at low $\mathrm{CFU}\left(<1 \times 10^{3} \mathrm{CFU}\right)$ and were not suitable for clinical studies. ${ }^{[4]}$ Drawing conclusions from this study, as no single assay had the 'ideal' balance of performance characteristics (specifically turnaround time and detection threshold), the choice of assay will largely depend on the study design. Other factors influencing choice of assay include: experimental question, dynamic range in which the measurements are conducted, the need for rapid determination of the result, desired reproducibility and available financial and laboratory resources. ${ }^{[4]}$ Additionally, if viability of the organisms needs to be determined, then assays such as the Xpert MTB/RIF will not be suitable as it is unable to differentiate between live or dead intact organisms.

A formal costing analysis, missing from this original publication, would provide additional information to researchers upon which to base the choice of assay in the given context that they work. We therefore conducted a comparative costing exercise of each of the assays employed using a single hypothetical experiment.

\section{Methods}

Laboratory assays

The methods for the mycobacterial load assays have been published in detail. ${ }^{[4]}$ Briefly, both BCG and H37RV luciferase reporter constructs (pSMT1 luciferase) were used for all assays. ${ }^{[5]}$ Triplicate serial 
dilutions were prepared in sterile phosphate buffer solution from the frozen stock for each strain in aliquots ranging from 1 to $1 \times 10^{6} \mathrm{CFU} / \mathrm{mL}$. The five predetermined assays were each performed using one of the prepared aliquots. In addition, all dilutions were inoculated onto solid media to confirm the number of CFUs at each dilution.

\section{Costing}

The cost of each technique was assessed by taking into account consumables used, personnel requirements and equipment. The purchase price of specific equipment and consumables for each experiment were obtained from local suppliers. Equipment costs per assay were determined using standard health economic methods. Costs were annualised using a $3 \%$ discount rate and the expected life years ranged from 10 to 20 years depending on the piece of equipment. It was assumed that $5 \%$ of the equipment usage would be allocated for each technique per year. Personnel costs were calculated by multiplying the per hour salary of a lab technician (University of Cape Town 2015 salary scales) by the estimated hands-on time to perform each assay. Costs were reported in 2015 South African rands and converted to United States dollars using an exchange rate of ZAR12.76 = USD1. Biosafety equipment costs were not included as they were assumed to be the same for all experiments.

A hypothetical single experiment, containing two conditions (control and intervention) performed in triplicate, was used to standardise cost between assays. Where appropriate, 'pooling of wells' was allowed to reduce costs, e.g. a single Xpert MTB/RIF cartridge for each condition (total of 2) as opposed to a single cartridge for each replicate (total of 6). Each of three $1 \mathrm{~mL}$ volumes were combined into one well and then mixed thoroughly, $1 \mathrm{~mL}$ of the combined wells was then used for the mycobacterial load calculation. Details of the costing sheet for each experiment are contained in Table 1. Additionally, the potential benefits and limitations of each technique were assessed on a simple qualitative scale. Factors included were: number of technical steps, time required to perform the assay, degree of automation and use of specialised reagents such as radioactive isotopes or luminescence substrates, which require specialised handling.
Table 1. Single experiment costing overview of mycobacterial load quantification assays

\begin{tabular}{|c|c|c|c|c|}
\hline Test & Item & $\begin{array}{l}\text { Estimated hands- } \\
\text { on time to perform } \\
\text { experiment (hours) }\end{array}$ & $\begin{array}{l}\text { Local supplier } \\
\text { purchase } \\
\text { price (ZAR) }\end{array}$ & $\begin{array}{l}\text { Cost per } \\
\text { experiment } \\
\text { (ZAR/USD) }\end{array}$ \\
\hline \multirow{6}{*}{ 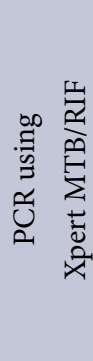 } & Consumables & - & - & R278.90 \\
\hline & Equipment & & & \\
\hline & $\begin{array}{l}\text { Gene Xpert IV } \\
\text { machine }\end{array}$ & - & R223 214 & R57.28 \\
\hline & Personnel & & & \\
\hline & Lab technician & 0.33 & - & $\mathrm{R} 51.84$ \\
\hline & $\begin{array}{l}\text { Total cost per } \\
\text { experiment }\end{array}$ & - & - & $\mathrm{R} 388.02 / \$ 30.42$ \\
\hline \multirow{6}{*}{ 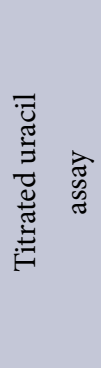 } & Consumables & - & - & $\mathrm{R} 110.43$ \\
\hline & Equipment & & & \\
\hline & $\begin{array}{l}\text { Beta counter \& } \\
\text { harvester }\end{array}$ & - & R849 297 & R118.93 \\
\hline & Personnel & & & \\
\hline & Lab technician & 1 & - & $\mathrm{R} 155.52$ \\
\hline & $\begin{array}{l}\text { Total cost per } \\
\text { experiment }\end{array}$ & & & $\mathrm{R} 384.88 / \$ 30.17$ \\
\hline \multirow{9}{*}{ 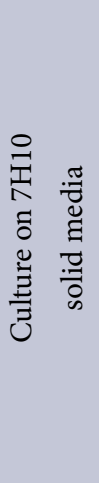 } & Consumables & - & - & R51.42 \\
\hline & Equipment & & & \\
\hline & Incubator & - & R22 000 & $\mathrm{R} 5.37$ \\
\hline & Autoclave & - & R56 940 & $\mathrm{R} 13.91$ \\
\hline & Microscope & - & R10 500 & $\mathrm{R} 2.56$ \\
\hline & Total equipment & - & R89 440 & $\mathrm{R} 21.84$ \\
\hline & Personnel & & & \\
\hline & Lab technician & 2 & - & R311.04 \\
\hline & $\begin{array}{l}\text { Total cost per } \\
\text { experiment }\end{array}$ & & & $\mathrm{R} 384.30 / \$ 30.13$ \\
\hline \multirow{6}{*}{ 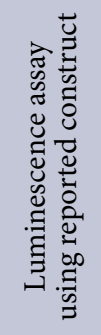 } & Consumables & - & - & R90.68 \\
\hline & Equipment & & & \\
\hline & Luminometer & - & R102 575 & $\mathrm{R} 25.05$ \\
\hline & Personnel & & & \\
\hline & Lab technician & 0.25 & - & $\mathrm{R} 38.88$ \\
\hline & $\begin{array}{l}\text { Total cost per } \\
\text { experiment }\end{array}$ & & & $\mathrm{R} 154.61 / \$ 12.12$ \\
\hline \multirow{6}{*}{ 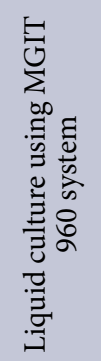 } & Consumables & - & - & R92.84 \\
\hline & Equipment & & & \\
\hline & $\begin{array}{l}\text { MGIT } 960 \\
\text { machine }\end{array}$ & - & R496 811 & $\mathrm{R} 121.34$ \\
\hline & Personnel & & & \\
\hline & Lab technician & 0.17 & - & $\mathrm{R} 25.92$ \\
\hline & $\begin{array}{l}\text { Total cost per } \\
\text { experiment }\end{array}$ & & & $\mathrm{R} 240.10 / \$ 18.82$ \\
\hline
\end{tabular}




\section{Results}

The component costs of for each assay are shown in Table 1. The cost per experiment for each technique ranged from R85.68/\$6.72 for the Luminescence assay to R388.02/\$30.42 for Xpert MTB/RIF PCR. The high cost of this assay was mainly attributable to the costly Xpert MTB/RIF cartridges. Although the CFU by solid culture had a similar cost compared with uracil incorporation and Xpert MTB/RIF, the purchase price of the equipment required to perform these assays was 2 - 10 times higher.

\section{CFU}

CFU counting had the lowest cost associated with reagents and did not require any specialised equipment other than that expected to routinely be in a Biosaftey Level 3 (BSL3) laboratory (autoclave, incubator and microscope). However, due to the time-consuming nature of the assay, personnel costs were the highest of any technique. The cost per experiment was estimated to be R384.30/\$30.13.

\section{Automated liquid culture}

As a semi-automated assay, the complexity and labour intensiveness was less than that of the CFU counting. The major cost for the experiment was the culture bottles, and estimated experimental costs were R240.10/\$18.82. However, start-up costs for this assay were also very high as the BACTEC MGIT system costs approximately R496 811 (developing country price).

\section{Luminescence}

The bioluminescence assay was the cheapest assay by far, costing R154.61/\$12.12 per experiment. However, despite providing an automated readout, the assay still required a significant degree of expertise in preparing the standard curve as well as using a specific reporter strain. The assay also requires the purchase of a luminometer, which has to be permanently situated in the biosafety laboratory.

\section{Uracil}

The uracil assay had the second highest cost of all the techniques (R384.88/\$30.17) and was attributable to the high personnel and equipment costs. This is particularly the case for the equipment, as both the cell harvester and liquid scintillation counter required for the assay costs $\sim$ R850 000. Additional requirements include expertise in handling radioactive material, appropriate storage and handling facilities and a complete lack of bacterial contamination in the sample.

\section{Xpert MTB/RIF}

For the costing analysis, the three replicates were pooled so that only two cartridges were used. Even using this strategy, the Xpert MTB/RIF PCR was still the most expensive, costing a total of R388.02/ $\$ 30.42$ per experiment, mainly because of the high cost of the Xpert MTB/ RIF cartridges. Start-up costs were also somewhat expensive as the Gene Xpert IV system costs R220 000(\$17 500) (developing country pricing).

Further details of the comparative costing are described in Table 2 for each assay as part of the overall performance incorporating the turnaround time and detection threshold from previously published data. ${ }^{[4]}$

\section{Discussion}

The range of costs in this hypothetical experiment varied from $\sim \mathrm{R} 150$ to R400 (\$10 - \$30). The main driver of the costs varied for each technique. Consumables and equipment drove the costs in the more automated systems, while personnel drove the costs of the more complex and labour-intensive techniques. Adding cost to the originally published performance characteristics did not cause any one technique to rise to the top as the 'best', as time, staffing and quantity of experiments required all add to costs, depending on the research setting. Although the luminescence assay was the 'cheapest option', this assay has poor discriminative ability and requires the use of a reporter strain. Therefore the suitability of this assay is limited, particularly in clinical settings. In contrast, solid culture was more expensive at R240 ( $\$ 18)$ per assay but had much better discriminative ability and no need for specialised equipment. Thus it is likely to remain a mainstay in many research institutions where equipment costs can be prohibitive. However, the long turnaround time, labour intensiveness, staffing time required and learning curve, may make automated options much more attractive where staffing costs are high and time is of the essence. ${ }^{[4]}$

The choice of assay, even with cost taken into account, will ultimately be a comprehensive feasibility evaluation. For example, evaluating tuberculosis sputum in a community could be done using a mobile Xpert machine, whereas a MGIT-BACTEC system would not be a feasible option for this research question. Additionally, the cost of the major equipment may be highly relevant in areas setting up new research laboratories or in remote areas where transport is problematic. In other centres where the equipment already exists, only running costs would need to be taken into account.

If many assays are to be performed, the capital costs may be offset by the platform's high throughput capacity. Where time is critical and staffing costs higher than what was used in this study, Xpert MTB/RIF may be a more cost-effective assay - although sacrificing detection of low organism loads. Xpert also detects $M$. tuberculosis DNA from both live and dead bacilli and is not suitable for research studies that require this distinction. Where precise determination of load and accurate discrimination between two mycobacterial loads are important, the CFU, although time-consuming and labour-intensive, may still be the best option.

Provided a given research laboratory has the basic equipment to conduct any given bio-hazardous experiment with virulent mycobacterium, additional costs and infrastructure would not generally be required except for the uracil assay. The infrastructure required to handle and dispose of radioactive chemicals and radioactive biohazardous waste is not available in many areas, making this unlikely to be cost-effective, especially in resource-poor settings. Biological samples are also not suitable for uracil or bioluminescence as the risk of contamination and spurious results are high and bioluminescence requires specific laboratory strains.

In clinical studies where a degree of quantitation of mycobacterial load is required, leveraging off existing infrastructure may provide a 
Table 2. Comparison of performance characteristics and cost

\begin{tabular}{|c|c|c|c|c|c|}
\hline Characteristic & $\begin{array}{l}\text { PCR using Xpert } \\
\text { MTB/RIF }\end{array}$ & Titrated uracil assay & $\begin{array}{l}\text { Liquid culture using } \\
\text { MGIT } 960 \text { system }\end{array}$ & $\begin{array}{l}\text { Luminescence assay } \\
\text { using reporter } \\
\text { construct }\end{array}$ & $\begin{array}{l}\text { Culture on } 7 \mathrm{H} 10 \\
\text { solid media }\end{array}$ \\
\hline $\begin{array}{l}\text { Result turn- } \\
\text { around time }\end{array}$ & Very quick & Quick & Slow & Very quick & Slow \\
\hline $\begin{array}{l}\text { Estimated } \\
\text { hands-on time } \\
\text { to perform assay } \\
\text { (minutes) }\end{array}$ & 20 & 60 & 10 & 15 & 120 \\
\hline $\begin{array}{l}\text { Detection } \\
\text { threshold }^{\dagger}\end{array}$ & Good & Poor & Excellent & Good & Excellent \\
\hline $\begin{array}{l}\text { Start-up costs } \\
\text { (equipment } \\
\text { purchase price) }\end{array}$ & $\begin{array}{l}\text { Medium-high } \\
\text { R223 214/\$17 } 500\end{array}$ & $\begin{array}{l}\text { Very high } \\
\text { R849 297/\$66 } 585\end{array}$ & $\begin{array}{l}\text { High } \\
\text { R496 811/\$38950 }\end{array}$ & $\begin{array}{l}\text { Medium } \\
\text { R102 575/\$8 } 042\end{array}$ & $\begin{array}{l}\text { Low R89 440/ } \\
\$ 7012\end{array}$ \\
\hline $\begin{array}{l}\text { Cost per } \\
\text { experiment }{ }^{\ddagger}\end{array}$ & High R388/\$30 & High R385/\$30 & Medium 240/\$19 & Low R155/\$12 & High R384/\$30 \\
\hline Pros & $\begin{array}{l}\text { Limited skills } \\
\text { required prior } \\
\text { to automated } \\
\text { processing }\end{array}$ & Semi-automated & $\begin{array}{l}\text { Limited training; } \\
\text { Automated system } \\
\text { once bottles } \\
\text { inoculated }\end{array}$ & $\begin{array}{l}\text { Very simple to } \\
\text { perform; least } \\
\text { costly }\end{array}$ & $\begin{array}{l}\text { High } \\
\text { discriminatory } \\
\text { value; } \\
\text { equipment } \\
\text { required } \\
\text { available in most } \\
\text { BSL3 facilities }\end{array}$ \\
\hline Cons & $\begin{array}{l}\text { Expensive } \\
\text { consumables } \\
\text { (Xpert cartridges); } \\
\text { cannot } \\
\text { distinguish } \\
\text { between live } \\
\text { and dead } \\
\text { M. tuberculosis }\end{array}$ & $\begin{array}{l}\text { Requires } \\
\text { radioactive isotope } \\
\text { handling skills and } \\
\text { regulatory approval }\end{array}$ & $\begin{array}{l}\text { High start-up } \\
\text { costs; equipment } \\
\text { usually available } \\
\text { only in specialised } \\
\text { tuberculosis labs }\end{array}$ & $\begin{array}{l}\text { Extensive } \\
\text { optimisation } \\
\text { required for each } \\
\text { strain and batch; } \\
\text { requires organism } \\
\text { with a fluorescent } \\
\text { reporter construct }\end{array}$ & $\begin{array}{l}\text { Very labour } \\
\text { intensive; } \\
\text { learning curve } \\
\text { for counting } \\
\text { colonies }\end{array}$ \\
\hline \multicolumn{6}{|c|}{ *Slow (days to weeks), quick 24 hours, very quick 2 hours. } \\
\hline \multicolumn{6}{|c|}{${ }^{\dagger}$ Excellent $<10$, good $\leq 100$, poor $\geq 1000$, adapted from Van Zyl-Smit. ${ }^{[4]}$} \\
\hline $\begin{array}{r}{ }^{*} \text { Costs were calculated for } \\
\text { pooled into a single bottl }\end{array}$ & $\begin{array}{l}\text { e specific consumables, equipme } \\
\text { tartridge to reduce costs. }\end{array}$ & and personnel for a $\mathrm{h}$ & & & \\
\hline
\end{tabular}

cost-effective option. To reduce the cost of preparing separate samples for CFU in the research laboratory, time to positivity using liquid culture (if performed) or cycle thresholds from the Xpert MTB/RIF assay could be used. These data are routinely determined as part of the automated assay but not always reported in a routine lab report as clinicians generally only need a yes/no answer upon which to make treatment decisions in acute hospital settings. Access to this information may provide (at no extra cost) a degree of quantification that will enhance the quantitative evaluation of clinical tuberculosis studies.

Salaries and equipment usage allocations may vary between research settings and will likely influence the cost of each assay. Even in reference laboratories it is suggested that there is balance of choice between performance characteristics, costs and need for rapid results. ${ }^{[5,6]}$ However, this is not expected to change the cost ranking of the techniques. Furthermore, batch processing of samples may also reduce consumable costs in some of these assays.

In conclusion, the choice of assay remains largely dependent on the research context, study question and the relative trade-offs of cost (both capital layout and on-going staffing) v. turnaround time. Access to quantitative information from liquid culture and Xpert MTB/RIF assays may enhance clinical studies at no extra cost where these assays are being routinely performed.

\section{References}

1. Dheda K, van Zyl-Smit R, Badri M, Pai M. T-cell interferon-gamma release assays for the rapid immunodiagnosis of tuberculosis: Clinical utility in high-burden vs. low-burden settings. Curr Opin Pulm Med 2009;15(3):188-200. [http://dx.doi. org/10.1097/MCP.0b013e32832a0adc]

2. Pai M, Kalantri S, Dheda K. New tools and emerging technologies for the diagnosis of tuberculosis: Part II. Active tuberculosis and drug resistance. Expert Rev Mol Diagn 2006;6(3):423-432. [http://dx.doi.org/10.1586/14737159.6.3.423]

3. Urdea M, Penny LA, Olmsted SS, et al. Requirements for high impact diagnostics in the developing world. Nature 2006;444 Suppl 1:73-79. [http://dx.doi.org/10.1038/ nature05448]

4. van Zyl-Smit RN, Binder A, Meldau R, Mishra H, Semple PL, Theron G, et al. Comparison of quantitative techniques including Xpert MTB/RIF to evaluate mycobacterial burden. PLoS One 2011;6(12):e28815. [http://dx.doi.org/ 10.1371/ journal.pone.0028815]

5. Kampmann B, Gaora PO, Snewin VA, Gares MP, Young DB, Levin M. Evaluation of human antimycobacterial immunity using recombinant reporter mycobacteria. J Infect Dis 2000;182(3):895-901. [http://dx.doi.org/10.1086/315766]

6. Shah M, Chihota V, Coetzee G, Churchyard G, Dorman SE. Comparison of laboratory costs of rapid molecular tests and conventional diagnostics for detection of tuberculosis and drug-resistant tuberculosis in South Africa. BMC Infect Dis 2013;13:352. [http://dx.doi.org/ 10.1186/1471-2334-13-352] 